\title{
Placed-based Education for Inquiry Learning
}

\author{
Lina Soares \\ Georgia Southern University \\ Georgia, USA
}

\begin{abstract}
In an effort to increase students' abilities to understand complex scientific concepts and to apply their understanding to investigate real-world problems, inquiry-based learning has become widely recognized and is a fundamental part of science education. The purpose of this site-based program was to involve science teachers directly in sea turtle research, rehabilitation, and conservation through placed-based education. The program was conducted through a university masters-level summer course at the Georgia Sea Turtle Center (GSTC) on historic Jekyll Island, Georgia. Funding was provided by a Teacher Quality Grant, formerly the Eisenhower Science and Mathematics Grants, while the project was in operation for four years. A one group pretestposttest design was implemented in order to answer the research question: 1) What impact does a placedbased experience have on science teachers' content knowledge of sea turtle conservation. The results from a paired samples t test showed there was a statistically significant difference between the content pretest and the content posttest. The implications suggest that the linkage between placed-based learning in science is of considerable importance for science programs.
\end{abstract}

\section{Introduction}

For the past couple of decades, the intense focus on achievement for all students has occurred due to the passing of the No Child Left Behind Act (NCLB) of 2001 (Pub. L. No. 107-110) [1]. The bill was reauthorized in 2015 as the Every Student Succeeds Act (ESSA) [2]. This federal piece of legislation brought forth increased standardization and accountability for schools, their teachers, and their students to be measured by state-mandated tests. However, one unintended consequence that occurred was that the curriculum was narrowed and instruction focused largely on content to be tested [3]. As a result, teachers in K-12 classrooms in the United States have been consumed with standards-based reform that has left little time for authentic learning such that scientific inquiry can permit. Despite the one size fits all mentality associated with NCLB [1] and ESSA [2], there is a growing trend for teaching and learning to connect students' lives in school to their community environment such that learning in physical places through inquiry occurs outside classroom walls.
Inquiry-based learning has become widely recognized and is a fundamental part of science education. It is an instructional method that allows students to learn scientific knowledge and concepts through hands-on activities from which students question, make observations, gather data, predict, and then form explanations as a means to understand scientific phenomena [4, 5]. Subsequently, inquiry- based classrooms are learner-centered and knowledge is constructed as the teacher is the facilitator who provides opportunities for students to interact, collaborate, and engage in authentic science activities $[6,7,8,9]$. However, for scientific inquiry to occur, teachers must develop inquiry-oriented learning opportunities that will engage students in collaborative activities to build scientific explanations as they examine the natural world $[10,11]$. One method that holds promise is placed-based learning. With this method, classroom science teachers can relate and apply the scientific concepts they teach in numerous settings and further permit their students to have equal access to understanding the nature of science.

The overarching goal of this project was to engage science teachers in scientific inquiry through placedbased learning by specifically focusing on sea turtle research, rehabilitation, and education. The program was conducted through a university masters-level summer course at the Georgia Sea Turtle Center (GSTC) on historic Jekyll Island, Georgia. Funding was provided by a Teacher Quality Grant, formerly the Eisenhower Science and Mathematics Grants, while the project was in operation for four years. What follows is an evaluation report of an eight- day total immersion summer residency program designed to provide an intensive hands-on, place- based science experience for in-service teachers. The report is based on the last summer the program was in operation. The report begins with a brief discussion on the meaning of placed-based education as an ideal context for students to engage in inquiry, followed by a brief discussion on the promotion of disciplinary literacy, and the benefits of placed-based education and reports on student achievement. The report continues with a discussion on the theoretical framework that supports placed-based learning, followed by a description of the summer course, an account of how the program objectives were measured for program fidelity, and the results. The report concludes with implications 
from the place- based learning experience and offers a few final remarks on placed-based learning as an experience for classroom teachers to consider for inquiry-based science curricula.

Pursuant to the above, the following research question guided the program evaluation: What impact does a placed-based experience have on science teachers' content knowledge of sea turtle conservation?

\section{Place-based Learning}

Utilizing students' local environments and communities for teaching and learning has become known as placed-based education [12]. At its core, Sobel [13] offers that placed-based education must be student- centered as the curriculum is developed from students' learning experiences within their community and from their local resources. It is a method of learning that permits students to explore topics through hands-on experiences [12]. From this stance, placed-based learning is grounded in the educational philosophy of experiential learning and it has become a recognized approach for inquiry [14]. Because inquiry-based classrooms are learner-centered, placedbased education is a good fit for students to engage in authentic science activities [6]. Additionally, the learner-centered focus permits students to work with their teachers to plan appropriate instructional activities to support content lessons and to plan the learning context. Placed-based education permits teachers to tap into the power of natural resources to give students hands-on, minds-on, and personalized learning experiences. Moreover, placed-based education promotes high academic outcomes and allows students to become change agents for the benefit of their community, the environment at- large, and its habitants [12]. As Sobel [13] has so aptly offered, placed-based education as:

“. . . the process of using the local community and environment as a starting point to teach concepts in language arts, mathematics, social studies, science, and other subjects across the curriculum" (p. 11).

From an interdisciplinary perspective, placed-based education offers an environment for the integration of science content and discipline-specific literacy skills grounded in inquiry. When process skills are grounded in inquiry in a science classroom, students then become the thinkers and scientists of the future. Placed-based learning affords science content teachers the opportunity to move their instruction beyond their classroom walls [12]. Moreover, it can be readily situated within students' communities such that teachers can draw upon their students' prior knowledge and from their local funds of knowledge [15]. Thus, all students have an equitable opportunity to participate in hands-on and minds-on science learning due to the fact that texts can be heavily laden with difficult vocabulary that prevents many students from acquiring the necessary content.

\section{Benefits of Place-based Learning}

In addition to the student-centered focus that placed-based learning offers, Martinez-Alveraz [16] explicated that placed-based pedagogy permits students with disabilities and bi-lingual students to acquire scientific content by drawing upon their cultural and linguistic knowledge that is frequently ignored in the classroom. Referred to as a third form of hybrid learning, placed-based pedagogy situates students in an environment where students can merge their out of school knowledge with their knowledge in the science classroom [16]. In conjunction, placedbased learning offers students the opportunity to question their place, to question their role in place, and to critically examine the imbalance of power in place, such as who benefits in a particular place and who is oppressed [17]. Greenwood [18] made the point that for educators to fully embrace inquiry such that placed-based education can provide, then they must employ critical pedagogies for students to understand the nature of self during interactions with others within the context of place. Thus, Greenwood [18] posited that critical pedagogy and placed-based education are inexplicably intertwined and believed that teachers cannot effectively teach their students to be stewards of their environment without understanding who benefits and why. "If we are at all interested in place, pursuing the questions [of why] needs to become a prominent feature of educational inquiry" [18].

\section{Promotes Discipline-Specific Language}

Scholars in the literacy field have long called for classroom teachers of all disciplines to instruct students on how to read, write, speak, listen, and think in each subject area. According to Greenleaf, et al. (2001), content area teachers "must know how to create a classroom culture of engaged disciplinary literacy" (p. 2) [19]. In conceptualizing disciplinary literacy, the author agrees with Shanahan and Shanahan [20] that disciplinary literacy is the set of skills specific to each discipline that students must possess in order to acquire and utilize the academic language and to read and comprehend content-specific instructional materials. In this regard, teachers plan their instruction to allow their students to think like an historian, mathematician, poet laureate, economist, and scientist [21]. According to Shanahan and Shanahan [22] for students to adopt discipline-specific skills, then students need full participation in the discipline.

In today's world, students need to learn both content and process skills in their subject disciplines. 
Hapgood and Palinscar (2007) [23] offered that a corequisite for science learning is literacy instruction. The language of science allows students to read, write, speak, view, and think as students engage in the study of scientific concepts. In addition, Pearson [24] explicated that proficient literacy skills permit students to extend and expand their scientific reasoning as they observe, predict, hypothesize, compare data, question data, and present findings. From this perspective, placed-based learning promotes the discipline-specific skills that Shanahan and Shanahan [20] refer. In other words, when students utilize the discipline-specific language needed for science in tandem with the space to explore scientific phenomena, then students become active participants in the inquiry process.

\section{Student Engagement and Achievement}

In an effort to increase student engagement, science teachers have long understood the motivation generated by outdoor education such that placedbased learning affords. Carrier-Martin [25] posited that outdoor learning experiences in science, not only increase students' awareness to their environment, but have positive effects on students' motivation and engagement. One well-known proponent of placedbased learning is the Place-based Education Evaluation Collaborative (PEEC) [26].

The PEEC is an organization that has been instrumental in laying the foundation for placed-based learning across twelve states involving many schools. Multiple research studies conducted by PEEC [26] have consistently shown that students who participate in placed-based education are more motivated and engaged in learning. Moreover, it is well-known that one common form of outdoor education has focused on school gardens. Skinner and Chi [27] investigated the effects of gardening on middle grades students' attitudes and engagement. Based on a pre and postmotivation survey, Skinner and Chi [27] found a positive and significant correlation between students' motivation and engagement to science and school. As a result, Skinner and Chi [27] offered that outdoor instruction not only builds student motivation but can further promote students' sense of accomplishment and partnership when engaged in an outdoor learning project.

Carrier-Martin [25] has offered that outdoor education also enhances students' appreciation for environmental issues; the heightened awareness and appreciation leads to greater student interest and science achievement afforded from placed-based learning experiences. A study that involved elementary school students engaged in an outdoor problem-based learning lesson in science concluded that the authenticity of the project increased the students' attitudes in science and science achievement [28].

\section{Theoretical Framework}

While placed-based learning is grounded in a number of theoretical frameworks, the author finds that Dewey's [29] learning by doing (progressivism), coupled with constructivism provide an appropriate theoretical foundation when discussing placed-based learning in science. As offered by Woodhouse and Knapp [30], "progressive educators have promoted the concept of place-based education for more than 100 years" (p. 1). As a progressive educator, Dewey [29] believed that learning should be active. He endorsed an experiential approach to student learning such that learning connects the place with the learner and the community through hands-on investigation and problem-solving [31]. Dewey [32] was an advocate that students' lives in school and students' lives away from school should be connected. The intention was to eliminate the disconnection between students and their community where the ultimate goal was for teachers and students to co-create the curricula. While Dewey's early writing in 1915 did not specifically state the name of placed-based learning, his words tend to frame this form of learning when he said, "Experience [outside the school] has its geographical aspect, its artistic and its literary, its scientific and its historical sides. All studies arise from aspects of the one earth and the one life lived upon it" (p. 91) [32].

From an epistemological standpoint, constructivists believe that students construct knowledge by interacting with their peers while engaged in authentic learning activities, and teachers serve as facilitators of a student-centered curriculum [33]. As students interact with the world around them, knowledge is formed by drawing upon prior learning in order to add new cognitive blocks or schema as suggested by Piaget [34] who endorsed the field of cognitive constructivism. In other words, knowledge is constructed. Additionally, the constructivist approach to learning endorses the tenet that learning should be relevant and that knowledge can be obtained through inquiry, problem-solving, applications of critical thinking, and reflection such that placed-based learning affords [35]. According to Sobel [13], constructivism endorses a learning approach where students are able to work collectively for the betterment of their communities that provide real-world environments for learning on site.

\section{Method}

The purpose of Sea Turtle 101 program was to involve science teachers directly in sea turtle research, rehabilitation, and education. In order to evaluate the program's fidelity, a one group pretest-posttest research design was implemented to determine the impact of a placed-based experience on science teachers' content knowledge of sea turtle 
conservation. Utilizing the Statistical Package for the Social Sciences (SPSS) version 21, a paired samples $t$ test was conducted to determine the impact from the placed-based experience.

\subsection{Participants and Site Description}

For the final summer program in this report, six Georgia state teachers assumed the role of scientists by participating in the process of scientific inquiry on sea turtle conservation and rehabilitation. The purpose was for the science teachers to experience the power of place to promote authentic leaning experiences. Additionally, the purpose was for the six teachers to engage in placed-based learning by assuming the role of scientists in order for them to actualize the merits of placed-based learning and to also transfer the scientific content learned to students in their classrooms. The program was conducted through a university masters-level summer course at the Georgia Sea Turtle Center (GSTC) on historic Jekyll Island, Georgia.

\subsection{Sea Turtle 101}

During the spring university semester, the six science teachers first participated in a full day preresidency workshop on campus. The purpose was to introduce the participants to barrier island geology and ecology and to build the students' background knowledge on sea turtle anatomy. The science teachers received content-specific texts to read and hand-outs on the five different types of sea turtles to build comprehension that would be needed to complete the course. It was during the pre-residency workshop that the science teachers were introduced to the academic vocabulary specific to the science content and given handouts on the interconnected reading, writing, and science skills they would be applying in the field. The science teachers were then given an assignment that required them to build a power point to illustrate sea turtle characteristics, adaptations, habitats, common nesting range, endangered level, life cycle, and facts of interest for the five species of sea turtles in this project. This assignment permitted the teachers to build sea turtle content knowledge prior to their on-site residency and further required them to actualize the connections between the discipline-specific skills of thinking like a scientist and science content.

To begin their eight-day residency on Jekyl Island, Georgia, the science teachers participated in activities designed to study sea turtles' life cycle, anatomy, food chains, and threats to survival. Specifically, the science teachers shadowed a rehabilitation technician to perform daily duties, such as feeding, cleaning the tanks, assisting the staff during turtle releases back to the sea, and monitoring sea turtles with night-time beach patrols that included protecting female turtles during the egg laying process. Additionally, the science teachers explored Georgia's coastal environment to deepen their understanding of barrier island ecology and to develop an appreciation for how suitable Georgia's barrier islands are to sea turtles' preservation and survival. During this time, the science teachers kept science journals to record data collected such as field notes, graphs, charts, photos, and utilized Web 2.0 resources. Participation in "Turtle Patrol" at night when female sea turtles come to shore allowed the teachers to observe sea turtle behavior in the wild and to learn about their nesting habits. Finally, the science teachers served as instructional hosts at the Georgia Sea Turtle Center to inform the public on sea turtle conservation and rehabilitation, answer questions about sea turtles, and provide power point lessons to the public while focusing on the interconnectedness between sea turtles and the barrier islands' ecosystems.

A post residency learning activity took place on St. Catherine's Island, Georgia during the fall university semester to engage the science teachers as a follow-up to their placed-based experience. On this day, the teachers participated in the care and treatment of sea turtle nests and hatchlings. The teachers put into practice their field science skills that included observing, sketching, measuring, and recording each nest to predict the location of the egg chamber within the greater nest structure. Each nest was then documented, sketched and/or photographed, and monitored. When sea turtle nests were found that were not in located in safe areas, the clutch of eggs was moved under the guidance of certified sea turtle technicians. As a culminating activity, the science teachers met on campus to share their classroom teaching experiences involving their own students. Specifically, they shared how they related the scientific content learned and how they related the language of science to students in their classrooms. Each of the science teachers created three lesson plans and videotaped one of the lessons to show to the group.

\subsection{Data Sources and Collection}

To address the research question, quantitative data were collected by administering a unit test for Sea Turtle 101 on a pre- posttest basis to determine if the eight-day course at GSTC improved the six participants' content knowledge. The unit test consisted of 40 multiple choice questions and was constructed to address the knowledge gained from participation in the five site-based activities. Specifically, questions 1-20 addressed the students' knowledge of sea turtle behavior and anatomy; questions 21-30 related to the students' knowledge of barrier island environments and ecology; and questions 31-40 addressed the students' knowledge of geological formation and change. 


\section{Analysis of Findings and Results}

To determine the impact of a placed-based experience on science teachers' knowledge of sea turtles, conservation, and rehabilitation efforts, the first step was to compute the science teachers' scores on the unit text for Sea Turtle 101. Means and standard deviations were calculated for both the pretest and the posttest. Utilizing the Statistical Package for the Social Sciences (SPSS) version 21, a paired samples $t$ test was then conducted; this was an appropriate statistical measure as the same participant sample was used before and after the treatment (see Table 1). The independent variable $(\mathrm{N}=6)$ was Sea Turtle 101 (the treatment) and the dependent variable $(\mathrm{N}=6)$ was content knowledge achievement. Scores on the unit test ranged from 1 to 100 with a mean of 50 (see Table 1).

The findings of the paired samples $t$ test showed there was a statistically significant difference between the content pretest $(\mathrm{M}=45.83, \mathrm{SD}=10.40)$ and the content posttest $(\mathrm{M}=78.00, \mathrm{SD}=7.75) ; t(5)=-7.23$, $\mathrm{p}=.001$. Two of the three content domains also showed a statistically significant difference. A statistically significant difference was found on the knowledge of rehabilitation and conservation for sea turtles (subscale 1) between the pretest $(M=41.67$, $\mathrm{SD}=7.53)$ and posttest $(\mathrm{M}=89.17, \mathrm{SD}=2.04) ; t(5)$ $=-14.16, \mathrm{p}=.000$. On knowledge of barrier islands (subscale 2), a statistically significant difference was found between the pretest $(\mathrm{M}=36.17, \mathrm{SD}=15.42)$ and the posttest $(\mathrm{M}=60.67, \mathrm{SD}=15.10) ; t(5)=-3.95$, $\mathrm{p}=.011$. Finally, there was no statistically significant difference found for knowledge of geology (subscale 3 ) between the pretest $(\mathrm{M}=66.67, \mathrm{SD}=24.56)$ and the posttest $(\mathrm{M}=59.50, \mathrm{SD}=18.25) ; t(5)=1.14, \mathrm{p}=$ .307 .

Table 1. Results of paired samples t test

\begin{tabular}{lcccc}
\hline & Mean Difference & SD & t & Sig. (2-tailed) \\
\hline Pair 1 Pretest-Posttest & 32.17 & 10.88 & -7.24 & .001 \\
$\begin{array}{c}\text { Pair 2 Pretest-Posttest } \\
\text { (subscale 1) }\end{array}$ & -47.50 & 8.22 & 14.16 & .000 \\
$\begin{array}{c}\text { Pair 3 Pretest-Posttest } \\
\text { (subscale 2) }\end{array}$ & -24.50 & 15.19 & -3.95 & .011 \\
$\begin{array}{c}\text { Pair 4 Pretest-Posttest } \\
\text { (subscale 3) }\end{array}$ & 7.17 & 15.42 & 1.14 & .307 \\
\hline
\end{tabular}

\subsection{Additional Findings}

As previously stated, the six classroom teachers met on campus as a culminating activity to share their classroom teaching experiences involving their own students. Specifically, they shared how and what they taught based on their scientific content learned relating to sea turtle characteristics, adaptations, habitats, common nesting range, endangered level, life cycle, and migratory patterns. Each of the classroom teachers created three lesson plans and videotaped one of the lessons to show to the group.

The video-taped lessons demonstrated how the experience from the course was used in their classrooms and reinforced the premise that the placedbased context provided an ideal setting for the science teachers to use their acquired knowledge and transfer the content knowledge to their classroom students by developing appropriate and meaningful lesson plans (Sobel, 2014) [14]. The lesson plans featured learning activities that engaged their classroom students in scientific inquiry related to the focus of endangered species, environmental issues brought on from human impact, sustainability with regards to the balance of salinity levels that sea turtles must maintain internally, and the topics of conservation and rehabilitation. Additionally, the lesson plans revealed the students were engaged in hands-on activities, critical thinking, and technology as a means to engage in further inquiry.

\section{Discussion}

The findings provided sufficient evidence that the science teachers gained significant knowledge of sea turtles and Georgia's coastal environment. The results of the paired samples $t$ test showed there was a statistically significant difference between the content pretest $(\mathrm{M}=45.83, \mathrm{SD}=10.40)$ and the content posttest $(\mathrm{M}=78.00, \mathrm{SD}=7.75) ; t(5)=-7.23, \mathrm{p}=.001$ and supports the premise that placed-based education enables students to leverage the power of place to promote high academic outcomes (PEEC, 2010) [26]. Additionally, the findings of the current study parallel the findings of Carrier- Martin (2003) [25] who found an increase in student engagement through outdoor learning and a heightened sense of environment. To first engage the science teachers, an initial presentation and tour was given to provide teachers with essential background knowledge. Teachers worked closely with GSTC staff and professionals to learn about sea turtle anatomy, physiology, and behaviors. Active participation in the areas of husbandry and in the GSTC hospital provided teachers with direct encounters with sea turtles and their survival needs. Throughout the week, participating teachers took on more responsibility for the care and treatment of sea turtles, while learning from the staff and medical team. In addition, the teachers worked closely with the general public and specific tour groups who visited the GSTC hospital by conducting educational programs to inform the public on sea turtle behaviors and anatomy. While the schedule and activities were demanding of each participant while at GSTC, the program provided a real-life view of the life of a scientist and the nature of science. Subsequently, Sea Turtle 101 provided 
multiple opportunities to interact, collaborate, and engage in authentic inquiry learning activities $[6,7$, 8]. Data collected during the residency were part of ongoing research conducted by scientists at GSTC and frequently involved beach turtle nighttime patrols. Participation in "Turtle Patrol" at night when female sea turtles come to shore allowed the teachers to observe sea turtle behavior in the wild and to learn about their nesting habits. When female sea turtles were sighted on the beach, the teachers were allowed to participate in data collection. First, it was necessary to record the exact geographical location by longitude and latitude where female sea turtles were spotted making a nest. This information was not only logged by GSTC staff, but by the teachers as well to keep an accurate record of the number of female sea turtles that came to shore as part of their ongoing research to understand sea turtle adaptations, ecological habitats, and common nesting range. Additionally, the six science teachers participated in the tagging process to identify and track the female sea turtles which provided additional data for the researchers to understand their survival habits while at sea. Throughout their time on Jekyll Island, Georgia, the six science teachers engaged in scientific inquiry and simulated the roles of scientist. This form of learning supports Dewey's [29] learning by doing and that knowledge is actively constructed. The teachers were exposed to and participated in numerous activities to build knowledge of sea turtles' life cycle, anatomy, food chains, and threats to survival. Through hands-on scientific inquiries, the placed-based experience required the science teachers to think, observe, question, and collect and analyze data; proficient literacy skills that support behaviors that are customary to scientists [24].

\subsection{Implications}

Sea Turtle 101 was designed and implemented to engage six science teachers in authentic placed-based activities that were directly linked to the sea turtles' immediate and future survival and to engage the teachers in hands-on inquiry activities that required them to actualize their disciplinary literacy skills. The implications from Sea Turtle 101 suggest that the linkage between placed-based learning in science is of considerable importance for classroom teachers to consider regarding the program delivery model for meeting the needs of their diverse learners. The placed-based learning environment enabled the six teachers to effectively communicate complex scientific concepts using the language of science as they engaged in scientific inquiry and reasoning [36]. In doing so, the experience further highlights the importance that placed-based learning supports interdisciplinary learning [13]. Specifically, the six classroom teachers were able to draw upon their knowledge of discipline-specific literacy skills to build evidence-based hypotheses and argue justifications [24]. Another implication is that attention must be paid to the learning environment. The structure of the placed-based learning context exemplifies the experiential approach to student learning that Dewey [29] first endorsed by connecting the place with the learner. Working alongside the GTSC staff in the areas of husbandry and participation in "Turtle Patrol" at night when female sea turtles came to shore to lay their eggs, implies that the placed-based learning experience became a site for knowledge construction. In other words, GSTC provided the six classroom teachers the opportunity to interact, collaborate, and to engage in meaningmaking activities based on the cognitive constructivist theory that knowledge is constructed [34]. Specifically, the experience allowed the science teachers to acquire knowledge of sea turtle conservation and rehabilitation, and in turn, communicate their understanding by conducting educational programs to inform both the public and their own classroom students.

\section{Conclusion}

Readers who have considered and possibly considering the implementation of placed-based learning, there are many resources with helpful steps. The following guidelines offered by McClennen [37] can be considered for establishing placed-based education:

- Inquire into place

- Identify challenges

- Revise and implement curriculum

- Build student ownership and skills

- Collaborate for an interdisciplinary unit

- Measure outcomes and successes

In practice, Sea Turtle 101 subscribed to the typical procedures and practices that are hallmarks of placedbased learning. The teachers in this report participated in a learner-centered teaching approach that included inquiry-based and hands-on instructional activities to improve science content for their classroom students. The instructional activities of this summer program were all developed to put an emphasis on the importance of investigating the local science content, i.e. the study of sea turtles' life cycle, anatomy, food chains, and threats to survival, and to draw upon the local resources to reinforce the science content. When considering placed-based learning, the six science teachers engaged in the process of scientific inquiry 
on sea turtle conservation and rehabilitation and transferred their knowledge to their own students in the study of scientific concepts.

\section{References}

[1] No Child Left Behind Act of 2001, P.L. 107-110, 20 U.S.C. $\$ 6319$ (2002).

[2] Every Student Succeeds Act of 2015, Pub. L. No. 114$95 \S 114$ Stat. 1177 (2015-2016).

[3] Au, W. (2007). High-stakes testing and curricular control: A qualitative metasynthesis. Educational Researcher, 36(5), 258-267.

[4] National Research Council. (2000). Inquiry and the national science education standards: A guide for teaching and learning. Washington, DC: National Academy Press.

[5] Parker, D. (2007). Planning for inquiry: It's not an oxymoron! Urbana, IL: National Council of Teachers of English.

[6] Anderson, R. D. (2002). Reforming science teaching: What research says about inquiry, Journal of Science Teacher Education, 13(1), 1-12.

[7] Burrow, A. (2018). Teaching introductory ecology with problem-based learning. Bulletin of the Ecological Society of America, 99(1), 137-150.

[8] Cianciolo, J., Flory, L., and Atwell, J. (2006). Evaluating the use of inquiry-based activities: Do student and teacher behaviors really change? Journal of College Science Teaching, 36(3), 50-55.

[9] Smallhorn, M., Young, J., Hunter, N., and da Silva, K. B. (2015). Inquiry-based learning to improve student engagement in a large first year topic. Student Success, 6(2), $65-71$.

[10] Metz, K. E. (2000). Young children's inquiry in biology: Building the knowledge bases to empower independent inquiry. In J. Minstrell and E.H. van Zee, (Eds.).Inquiry into inquiry learning and teaching in science (pp. 371-404). Washington, DC: American Association for the Advancement of Science.

[11] Sarkar, S., and Frazier, R. (2008). Placed-based investigations and authentic inquiry, The Science Teacher, 75(2), 29-33

[12] Gruenewald, D. A., and Smith, G. A. (Eds.). (2008). Place-based education in the global age: Local diversity. New York: Lawrence Erlbaum.

[13] Sobel, D. (2004). Place-based education: Connecting classrooms and communities. Barrington, MA: Orion Society.

[14] Sobel, D. (2013). Place based education: Connecting classrooms and communities (2 ed.). Great Barrington, MA: The Orion Society.
[15] González, N., Moll, L. C., and Amanti, C. (2005) Funds of knowledge: Theorizing practices in households, communities, and classrooms. Mahwah, NJ: Lawrence Erlbaum.

[16] Martinez-Alverez, P. (2017). Special ways of knowing in science: expansive learning opportunities with bilingual children with learning disabilities. Cultural Studies of Science Education, 12(3), 521-553.

[17] Gruenewald, D. (2003). The best of both worlds: A critical pedagogy of place. Educational Researcher, 32(4), 3-12.

[18] Greenwood, D. A. (2008). A critical pedagogy of place: From gridlock to parallax. Environmental Education Research, 14(3), 336-348.

[19] Greenleaf, C., Schoenbach, R., Cziko, C., and Mueller, F.L. (2001). Apprenticing adolescent readers to academic literacy. Harvard Educational Review, 71, 79-129.

[20] Shanahan, T., and Shanahan, C. (2008). Teaching disciplinary literacy to adolescents: Rethinking content area literacy. Harvard Educational Review, 78(1), 40-59.

[21] Wineburg, S., and Reisman, A. (2015). Disciplinary literacy in history. Journal of Adolescent and Adult Literacy, 58(8), 634-637.

[22] Shanahan, T., and Shanahan, C. (2012). What is disciplinary literacy and why does it matter? Topics in Language Disorders, 32(1), 7-18.

[23] Hapgood, S., and Pallincsar, A.S. (2007). Where literacy and science intersect. Education Leadership, 64 (4), 56-60.

[24] Pearson, P. (2010). Literacy and science: Each in the service of the other. Science, 328, 450-463.

[25] Carrier-Martin, S. (2003). The influence of outdoor schoolyard experiences of students' environmental knowledge, attitudes, behaviors and comfort levels. Journal of Elementary Science Education, 15 (2), 51-63.

[26] Place-based Education Evaluation Collaborative. (2010). Benefits of place-based education: A report from the Place-based Education Evaluation Collaborative ( $2^{\text {nd }}$ ed.). http://tinyurl.com/PEECBrochure. (Access Date: 12 September 2021).

[27] Skinner, E., and Chi, U. (2012). Intrinsic motivation and engagement as active ingredients in garden-based education: Examining models and measures derived from self-determination theory. The Journal of Environmental Education, 43(1), 16-36.

[28] Vasconcelos, C. (2012). Teaching environmental education through PBL: Evaluation of a teaching intervention program. Research in Science Education, 42(2), 219-232.

[29] Dewey, J. (1938). Experience and education. New York: Macmillan Company. 
[30] Woodhouse, J., and Knapp, C. (2000). Place-based curriculum and instruction: Outdoor and environmental education approaches. ERIC Digest.

[31] Sarkar, S., and Frazier, R. (2008). Place-based investigations and authentic inquiry. The Science Teacher, $75,29-33$.

[32] Dewey, J. (1915). The school and society (Rev. ed.). Chicago, IL: The University of Chicago Press.

[33] Khalid, A., and Azeem, M. (2012). Constructivist vs traditional: Effective instructional approach in teacher education. International Journal of Humanities and Social Science, 2(5), 170-177.

[34] Piaget, J. (1936). Origins of intelligence in the child. London: Routledge and Kegan Paul.

[35] Driscoll, M. (2000). Psychology of learning for instruction ( $2^{\text {nd }}$ ed.). Needham Heights, MA: Allyn and Bacon.

[36] Douglas, R., Klentschy, M. P., Worth, K., and Binder, W. (Eds.). (2006). Linking science and literacy in the K-8 classroom. Arlington, VA: NSTA Press.

[37] McClennen, N. (2017). 6 phases of professional placed-based learning. Getting Smart https://www.gettings mart.com/2017/02/13/6-phases-place-based-learning/.

(Access Date: 12 September 2021). 